\title{
THE LIVING STANDARDS OF RUSSIA'S POPULATION IN Q1 2013
}

\author{
S.Misikhina
}

Over the first 4 months of 2013, the population's real disposable income over the first 4 months of 2013 rose by $5.9 \%$ on the corresponding period of 2012, which happened due to an increase in the size of both wages and pensions. The inequality indices on Q1 2013 remained practically the same as in the corresponding period of last year. The poverty indices in 2012 were the lowest of the entire period of 1992-2012.

In April 2013, the population's nominal per-capita money income amounted to Rb 25,439 per month; in Q1 2013 it was at the level of Rb 21,204.0; in March - Rb 23,462.3. Nominal money income growth in April 2013 amounted to 8.4\%; over the period of January-April 2013 it rose to $113.2 \%$ on the corresponding period of 2012 ; while over the first four months of 2012 the population's nominal money income increased on the same period of 2011 by $6.3 \%$.

Over the course of Q1 2013, the real disposable money income of the population dropped by $24.3 \%$ on Q4 2012, which is quite compatible with the seasonal downward movement of that index after the traditional payment of bonuses, additional remunerations, etc. at the end of a year (in Q1 2012 this drop amounted to 24\%). By comparison with Q1 2012, the growth of real disposable money income of the population in Q1 2013 was higher by 5.3\% (over the same period a year earlier this figure amounted to 1.6\%). In April, the population's real disposable money income was still on the rise, and so its index increased on March by $7.4 \%$.

CHANGES IN REAL DISPOSABLE MONEY INCOME, \%

\begin{tabular}{|c|c|c|}
\hline \multirow{2}{*}{} & \multicolumn{2}{|c|}{ as percentage of } \\
\cline { 2 - 3 } & $\begin{array}{c}\text { corresponding period } \\
\text { of previous year }\end{array}$ & of previous period \\
\hline Q1 & 99.4 & 76.0 \\
\hline Q2 & 98.9 & 113.2 \\
\hline Q4 & 101.9 & 100.4 \\
\hline Год & 101.5 & 118.1 \\
\hline & 100.4 & \\
\hline Q1 & 101.6 & 75.7 \\
\hline April & 101.3 & 108.3 \\
\hline January-April & 101.5 & 115.9 \\
\hline Q2 & 104.4 & 100.9 \\
\hline Q3 & 104.9 & 119.0 \\
\hline Q4 & 105.8 & \\
\hline Year & 104.4 & 75.7 \\
\hline & 105.3 & 107.4 \\
\hline Q1 & 107.3 & \\
\hline April & 105.9 & \\
\hline January-April & \multicolumn{2}{|c|}{2013} \\
\hline
\end{tabular}

Source: data released by Rosstat.

In April 2013, the average monthly charged wage of a worker rose to $\mathrm{Rb} 28,836$. Taking the first four months of 2013 together, the real average monthly charged wage was $\mathrm{Rb} 27,714$. As a percentage of the previous period, the nominal monthly charged wage of a worker in April 2013 was 
100.5\% compared to March 2013; in Q1 2013 as a whole it was 90.4\% compared to Q4 2012 (in the corresponding periods of 2012 it had been $101.2 \%$ and $90.7 \%$ respectively). By comparison with the corresponding periods of last year, the nominal monthly charged wage of a worker in Q1 2013 rose to $111.9 \%$; in April - to $111.7 \%$; and over the first 4 months of 2013 - to $111.8 \%$.

The real average monthly charged wage in April 2013 remained at the same level as in March. The value of that index for Q1 2013 dropped on Q4 2012 by 11.3\% (over the corresponding period of 2012 its decline had amounted to 10.5\%). By comparison with the corresponding period of 2012, in Q1 2013 the real average monthly charged wage increased by 4.5\% (over the period of January-April - by 4.3\%).

The downward trend that has been displayed by wages in arrears since 2009-2010 seems to have disappeared by 2013: from February onwards, this index has been higher that its value over the corresponding period of last year. Practically always the presence of wages in arrears could be explained by the relevant organizations' lack of their own resources, mainly caused by difficulties in attracting loans and the low profitability of one or other organization. The volume of wages in arrears as of the beginning of May amounted to approximately $1.2 \%$ of companies' total monthly wages fund (as seen by data for the types of economic activity under consideration).

Table 2

WAGES IN ARREARS (AS OF YEAR'S END, MILLIONS OF RUBLES)

\begin{tabular}{|l|l|l|l|l|l|l|}
\hline Total, for types of economic activity under consideration & 2007 & 2008 & 2009 & 2010 & 2011 & 2012 \\
\hline
\end{tabular}

Source: data released by Rosstat.

WAGES IN ARREARS, MILLIONS OF RUBLES (AS OF MONTH'S BEGINNING)

\begin{tabular}{|c|c|c|c|c|c|}
\hline & January & February & March & April & May \\
\hline 2012 & 1,766 & 1,954 & 1,805 & 2,030 & 1,915 \\
\hline 2013 & 1,560 & 2,296 & 2,404 & 2,568 & 2,517 \\
\hline
\end{tabular}

Source: data released by Rosstat.

From 1 February 2013, labor pensions were upwardly adjusted: the indexation amounted to 6.6\%.

From 1 April 2013:

- an additional indexation of labor pensions was introduced due to the increasing income of the RF Pension Fund, which resulted in the amount of pensions increasing by $3.3 \%$,

- an upward index was applied to state pensions, including social pensions; those increased by $1.81 \%$.

In March 2013, the average size of pension amounted to $\mathrm{Rb} 9,859$. As a percentage of the previous period, in Q1 2013 this index was 102.4\% compared to Q4 2012 and 102.9\% compared to Q1 2012.

The population's socio-economic differentiation in Q1 2013 remained practically at the same level as a year earlier.

POPULATION DISTRIBUTION BY AVERAGE PER CAPITA INCOME, \%

\begin{tabular}{|l|c|c|}
\hline $\begin{array}{l}\text { Money income, } \\
\text { including by population quintiles }\end{array}$ & Q1 2013 & Q1 2012 \\
\hline first quintile (lowest incomes) & 100 & 100 \\
\hline second quintile & 5.5 & 5.5 \\
\hline third quintile & 10.3 & 10.3 \\
\hline fourth quintile & 15.2 & 15.2 \\
\hline fifth quintile (highest incomes) & 22.7 & 22.7 \\
\hline Rini coefficient (income concentration index) & 46.3 & 46.3 \\
\hline R/P 10\% & 0.404 & 0.403 \\
\hline
\end{tabular}

Source: data released by Rosstat. 
The data pointing to a stable upward movement of the index of inequality in the distribution of the population's money incomes is confirmed by the positive changes in the average per-capita money income distribution: the share of population in the low-income groups was declining, while in the higher-income groups it was on the rise.

Table 5

POPULATION DISTRIBUTION BY AVERAGE PER CAPITA INCOME, \%

\begin{tabular}{|c|c|c|}
\hline & Q1 2013 & Q1 2012 \\
\hline Total population & 100 & 100 \\
\hline $\begin{array}{l}\text { Including with average per capita income } \\
\text { per month, rubles } \\
\text { under } 5,000.0\end{array}$ & 6.0 & 7.9 \\
\hline $5,000.1-7,000.0$ & 7.4 & 8.9 \\
\hline $7,000.1-10,000.0$ & 13.0 & 14.6 \\
\hline $10,000.1-14,000.0$ & 16.4 & 17.3 \\
\hline $14,000.1-19,000.0$ & 16.2 & 16.0 \\
\hline $19,000.1-27,000.0$ & 16.7 & 15.5 \\
\hline $27,000.1-45,000.0$ & 15.9 & 13.6 \\
\hline over $45,000.0$ & 8.4 & 6.2 \\
\hline
\end{tabular}

Source: data released by Rosstat.

Poverty. As we forecasted in our previous publications, the poverty indices for 2012 declined to a lower level than in 2011. Moreover, it should be noted that the poverty indices for 2012 represent a historic low of the entire period of 1990-2011. The positive trends in the movement of poverty indices in the late 2000s and early 2010s were caused both by the increasing income of the population coupled with negligible changes in the inequality index and by the increased social transfers (when pensions were increased and upwardly adjusted, and some other welfare benefits

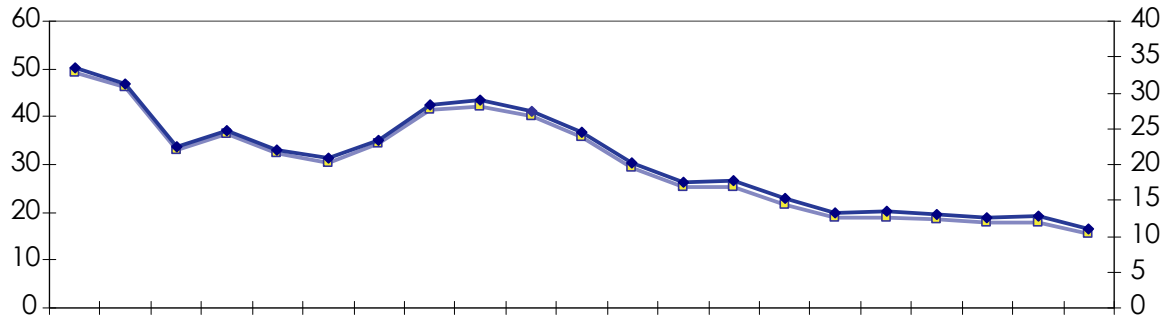

199219931994199519961997199819992000200120022003200420052006200720082009201020112012

$\rightarrow$ number of people with money incomes below subsistence level, millions $\rightarrow$ share of the 'poor' population, \% of total population

Source: data released by Rosstat.

Fig. 1. The Movement of the Poverty Indices in Russia

were increased as well). 